\title{
Seasonal and spatial influences on gene expression in Antarctic krill Euphausia superba
}

\author{
Paul J. Seear ${ }^{1,2}$, William P. Goodall-Copestake ${ }^{1}$, Andrew H. Fleming ${ }^{1}$, Ezio Rosato ${ }^{3}$, \\ Geraint A. Tarling ${ }^{1, *}$
}

${ }^{1}$ British Antarctic Survey, Natural Environment Research Council, High Cross, Madingley Road, Cambridge CB3 0ET, UK

${ }^{2}$ Department of Biology, and ${ }^{3}$ Department of Genetics, University of Leicester, University Road, Leicester LE1 7RH, UK

\begin{abstract}
The high latitudes inhabited by Antarctic krill Euphausia superba Dana are characterised by extreme changes in seasonal conditions, with very low food availability, long periods of darkness and a massive expansion of sea ice in autumn and winter. How krill adapt to these conditions has yet to be determined, and it was the purpose of this study to gain more insight by investigating the differences between summer and winter krill populations at the molecular level. To achieve this, we used a cDNA microarray to compare gene expression between female adult krill caught during summer and winter near the Antarctic Peninsula $\left(60^{\circ} \mathrm{S}\right)$, and between Peninsula krill and krill caught near South Georgia $\left(54^{\circ} \mathrm{S}\right)$ during the same winter. The Peninsula seasonal comparison showed up-regulation in summer krill of genes involved in feeding and digestion, respiration, motor activity and immunity. Summer krill also showed evidence of increased vitellogenesis, with an insulin-related peptide up-regulated and neuroparsin down-regulated. The comparison between the different overwintering locations showed an up-regulation in the South Georgia krill of genes involved in feeding and digestion, and immunity. There was, however, no differential expression of genes involved in respiration, motor activity or vitellogenesis, suggesting that despite the above differences, both populations of overwintering krill were in a quiescent state. This study shows how krill physiology changes seasonally at the molecular level and how these changes are flexible according to the overwintering environment.
\end{abstract}

KEY WORDS: Southern Ocean · Genomics · Physiology · Feeding · Reproduction · Immuneresponse $\cdot$ Overwintering $\cdot$ Quiescence

\section{INTRODUCTION}

Antarctic krill Euphausia superba is one of the most abundant multicellular species on earth, with an estimated biomass of between 100 and 500 million tonnes (wet mass) and an annual production of a roughly similar amount (Atkinson et al. 2009). It is an important component of the Southern Ocean ecosystem, acting as a major link between primary production and the higher-order predators (Laws 1985). It is also the target of a fishery in the Southern Ocean (Croxall \& Nicol 2004) which presently extracts around 200000 tonnes per year (CCAMLR 2010). For much of the year, krill are highly active and have an energy throughput of around $20 \%$ of body carbon per day or higher, which is sustained by a high and effective rate of filtration of phytoplankton (Quetin et al. 1994).

Seasonal changes in the habitat of Antarctic krill can be dramatic. Towards the southern reaches, there is near constant darkness during mid-winter and almost constant light in mid-summer. Sea ice expands from a summer minimum of $4 \times 10^{6} \mathrm{~km}^{2}$ to a winter maximum of $18 \times 10^{6} \mathrm{~km}^{2}$ (Parkinson 2002). Primary productivity fluctuates between major phytoplankton blooms in spring and summer, to very low phytoplankton concentrations in autumn and winter (El-Sayed 1988), such that there are long periods of low food availability, particularly during the winter 
(Clarke \& Morris 1983, Quetin et al. 1994). The ability of krill to adapt their life-cycle to account for these seasonal changes is likely to be a major factor behind their success in the Southern Ocean.

For ectothermic pelagic animals in polar regions, Torres et al. (1994) proposed that 3 types of overwintering strategy exist: (1) accumulating large lipid deposits and entering true dormancy; (2) a marked reduction in metabolic rate, combustion of body substance, opportunistic feeding, but no true dormancy; and (3) a 'business as usual' scenario, where opportunistic feeding continues and the metabolic rate is not considerably reduced. Antarctic krill were considered to exhibit Strategy 2, becoming quiescent but able to exploit food resources if any become readily available.

Quetin \& Ross (1991) proposed that, during overwintering, almost three-quarters of energy is saved by a reduction in metabolism, with much of the remainder coming from the use of lipids and shrinkage. Quetin et al. (1994) considered that a lowered oxygen consumption rate is to be expected since the metabolic costs associated with reproduction and growth are greatly reduced. Nevertheless, even taking this into account, adults still use up almost half of their stored lipid during the low food periods of autumn and winter (Hagen et al. 1996). Switching to alternative food sources, such as copepods (Boyd et al. 1984) and detritus (Kawaguchi et al. 1986) during the winter has been described but remains difficult to quantify. There may also be regional winter food sources, such as the sea ice microbial community, available to populations inhabiting the seasonal sea ice (Smetacek et al. 1990), or organic matter on the seabed, available to populations within shelf regions (Schmidt et al. 2011), but their overall contribution to the winter energy budget of krill remains undetermined.

Reduced metabolic rates during winter have been observed in Antarctic krill in a number of different areas (Morris \& Priddle 1984, Quetin \& Ross 1991, Atkinson et al. 2002, Meyer et al. 2002, Cullen et al. 2003). Nevertheless, it remains unclear whether a seasonal change in metabolic rate simply reflects a change in ingestion rate, or alternatively, a more fundamental switch to a different physiological state, cued by external or internal factors (Meyer et al. 2002, Meyer 2012). Evidence for the former is presented by Ikeda \& Dixon (1982) who showed krill starved for $24 \mathrm{~h}$ lower their oxygen uptake to $63 \%$ of that of wild specimens. In support of the latter, Atkinson \& Snyder (1997) and Atkinson et al. (2002) found that autumn krill do not raise their relatively low feeding rate when placed in food-saturated conditions, consistent with a state of quiescence. Meyer et al. (2010) proposed that entry and exit from overwintering quiescence is triggered by the photoperiod or light level. For instance, the light regime triggers the onset of reproductive maturation (Hirano et al. 2003, Teschke et al. 2008) and alters the rate of oxygen consumption and feeding (Teschke et al. 2007). Seear et al. (2009) showed that gene expression patterns may change within $7 \mathrm{~d}$ of being exposed to an altered light regime.

The overwintering experience of krill depends much on their location. Those found further south experience shorter summers and longer winters than more northerly populations. A further consideration is that krill are capable of travelling great distances across many degrees of latitude, even within a single season (Thorpe et al. 2007), meaning that the photoperiodic regime experienced by an individual krill may alter beyond that resulting from regular seasonality. This makes it unlikely that there is a single cue controlling overwintering behaviour. Accordingly, Brown et al. (2011) showed that the timing of the krill maturity cycle is flexible and can be manipulated through exposure to periods of darkness.

Molecular mechanisms driving overwintering behaviour include transcriptional, post-transcriptional and post-translational processes (MacRae 2010). Transcriptional processes driving the expression of RNA from genes represent the first level of control. Single-gene expression studies have revealed a great deal about the response of organisms to environmental stressors, such as the role of heat-shock proteins in thermal adaptation (Feder \& Hofmann 1999). However, multiple-gene studies have shown that responses to environmental stress are likely to be expressed in a wide range of genes, demanding a much broader approach (Stillman et al. 2008). Modern multiple-gene expression approaches allow the expression of thousands of genes to be examined simultaneously, and have led to a new level of understanding of physiological responses of crustaceans to environmental change (Colbourne et al. 2011). They have also revealed much about internal processes of crustaceans such as reproduction (Nagaraju 2011), immune response (Aoki et al. 2011), inducible defense (Tollrian \& Leese 2010), diapause (MacRae 2010) and starvation (Lenz et al. 2012). In Antarctic krill, Seear et al. (2010) used cDNA microarray techniques to examine differential gene expression during successive phases of the moult cycle. Clark et al. (2011) applied 454 pyrosequencing and found high levels of expression of classical 'stress proteins' such as HSP70, HSP90, ferritin and GST in Antarctic krill. Such techniques can contribute considerably to our 
Fig. 1. Sampling locations at the Antarctic Peninsula and South Georgia. Refer to Table 1 for further details on coordinates, dates and accompanying environmental information. Fine lines demark water mass boundary positions during summer 2008 determined from dynamic height data: SB southern boundary, SACCF southern Antarctic circumpolar current front, S-PF - southern polar front, N-PF - northern polar front. Grey broken lines mark the $500 \mathrm{~m}$ depth contour

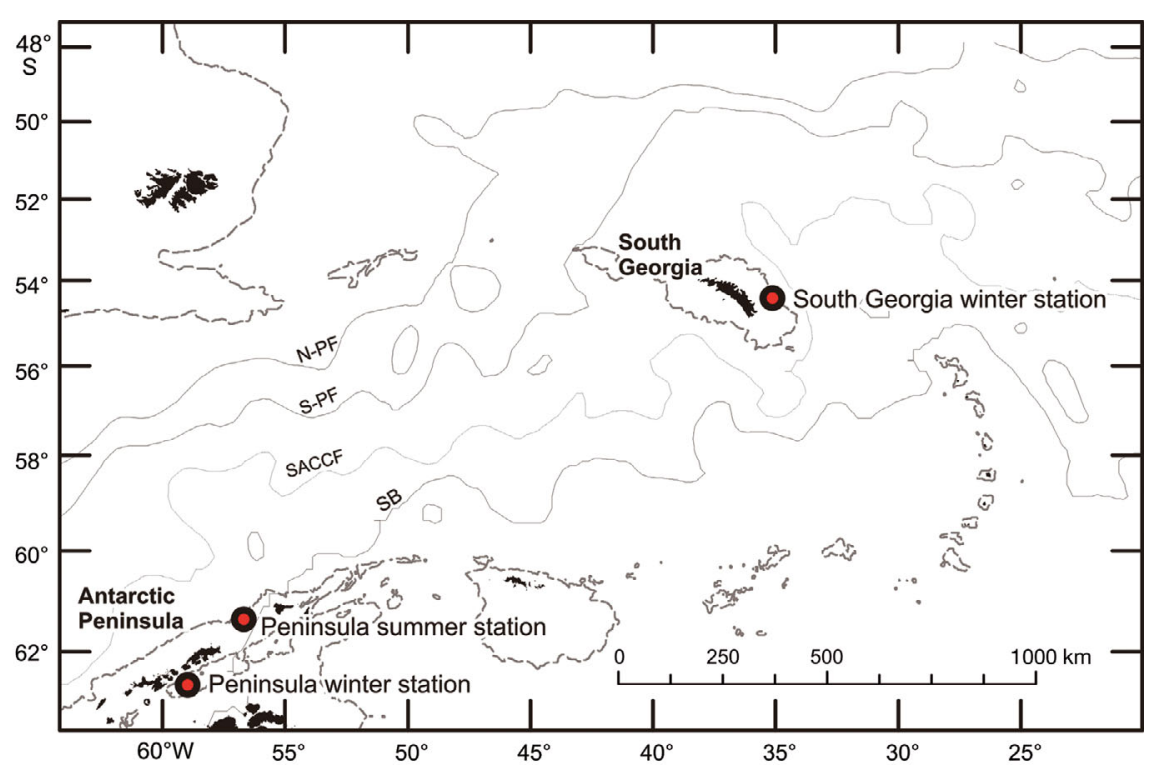

genes, indicating that this is a key step in controlling seasonal physiological change; (2) which genes change expression levels between seasons; and (3) whether the pattern of overwintering gene expression is similar or different between regions, namely between the Antarctic Peninsula and South Georgia.

\section{MATERIALS AND METHODS}

\section{Krill capture and preservation}

Postlarval krill were sampled at 2 main locations (Fig. 1), one close to the Antarctic Peninsula and the other at South Georgia, by the RRS 'James Clark Ross' and the krill fishery vessel 'Saga Sea' (Table 1). The krill were caught with target net tows in the top $200 \mathrm{~m}$. On the JCR cruise, they were placed immediately in RNAlater (Applied Biosystems). On the fishery vessels, they were immediately placed at $-20^{\circ} \mathrm{C}$ and stored over the longer term at $-80^{\circ} \mathrm{C}$. In the laboratory, the heads were taken for RNA extraction

Table 1. Locations and times of krill catches plus accompanying sampling information and environmental data

\begin{tabular}{|c|c|c|c|c|c|c|c|c|c|}
\hline Sample location & $\begin{array}{l}\text { Date of } \\
\text { sampling }\end{array}$ & Latitude & Longitude & Ship & Storage & $\begin{array}{l}\text { Water } \\
\text { depth }\end{array}$ & SST & $\begin{array}{l}\text { Distance }(\mathrm{km}) \\
\text { from ice edge }\end{array}$ & $\begin{array}{l}\text { Water } \\
\text { mass }\end{array}$ \\
\hline $\begin{array}{l}\text { Antarctic Peninsula } \\
\text { winter }\end{array}$ & $\begin{array}{l}\text { June } \\
2006\end{array}$ & $\begin{array}{l}62.6^{\circ} \mathrm{S} \text { to } \\
63.1^{\circ} \mathrm{S}\end{array}$ & $\begin{array}{l}59.1^{\circ} \mathrm{W} \text { to } \\
59.4^{\circ} \mathrm{W}\end{array}$ & $\begin{array}{l}\text { 'Saga } \\
\text { Sea' }\end{array}$ & $\begin{array}{l}\text { Flash } \\
\text { frozen }\end{array}$ & $1302 \mathrm{~m}$ & $-1.16^{\circ} \mathrm{C}$ & $<50$ & $\begin{array}{l}\text { SB to } \\
\text { SACCF }\end{array}$ \\
\hline $\begin{array}{l}\text { Antarctic Peninsula } \\
\text { summer }\end{array}$ & $\begin{array}{l}\text { January } \\
2003\end{array}$ & $\begin{array}{l}60.4^{\circ} \mathrm{S} \text { to } \\
60.8^{\circ} \mathrm{S}\end{array}$ & $\begin{array}{l}55.0^{\circ} \mathrm{W} \text { to } \\
54.8^{\circ} \mathrm{W}\end{array}$ & $\begin{array}{c}\text { 'James } \\
\text { Clark Ross' }\end{array}$ & RNAlater & $3373 \mathrm{~m}$ & $1.61^{\circ} \mathrm{C}$ & $200-500$ & $\begin{array}{l}\text { SB to } \\
\text { SACCF }\end{array}$ \\
\hline $\begin{array}{l}\text { South Georgia } \\
\text { winter }\end{array}$ & $\begin{array}{l}\text { July } \\
2006\end{array}$ & $53.5^{\circ} \mathrm{S}$ & $35.6^{\circ} \mathrm{W}$ & $\begin{array}{l}\text { 'Saga } \\
\text { Sea' }\end{array}$ & $\begin{array}{l}\text { Flash } \\
\text { frozen }\end{array}$ & $3415 \mathrm{~m}$ & $0.00^{\circ} \mathrm{C}$ & $>500$ & $\begin{array}{l}\text { SACCF } \\
\text { to S-PF }\end{array}$ \\
\hline
\end{tabular}


while the remainder of the body tissue was used for measurement of uropod length, sex, sexual stage and moult stage. Studies of transcriptional expression were limited to those individuals in the intermoult stage (stage C) (Buchholz 1982) that were female but yet to mature fully (stage IIB or IIIA) (Makarov \& Denys 1980). This step was carried out to avoid gene expression differences between sexes or moult stages from dominating the comparison (see Seear et al. 2010). Altogether, 126 krill were examined, from which 37 krill suited the above criteria: 11 from Peninsula winter samples, 18 from Peninsula summer samples, and 8 from South Georgia winter samples.

\section{Environmental conditions at sampling sites}

Satellite images of sea surface temperature (SST) and sea ice cover were examined to place the sampling locations within an environmental context. Sea surface temperature was acquired by the Aqua MODIS instrument and made available through the JPL PODAAC POET service with $4 \mathrm{~km}$ pixel spacing. Sea ice concentration data was derived from AMSRE data provided by the University of Bremen, with a pixel spacing of $4 \mathrm{~km}$. SST and sea ice data were binned into monthly composites covering the month of sampling and the 2 preceding months. The coverage of Aqua MODIS chlorophyll a (chl a) data, provided by the NASA Ocean Color group, was insufficient to resolve surface chl a conditions at the sampling sites.

\section{Construction of winter krill cDNA libraries}

Total RNA was extracted from the frozen heads (including eyes and brain) of 6 randomly selected krill from the Peninsula winter and South Georgia winter samples using TriSure (Bioline) followed by purification with RNeasy columns (Qiagen). Concentration and purity of the total RNA was determined using a Nanodrop spectrophotometer (LabTech International), while degradation was checked by electrophorescing $1 \mu \mathrm{g}$ of total RNA on a non-denaturing $1.5 \%(\mathrm{w} / \mathrm{v})$ agarose gel. Equal amounts of total RNA from each of the 6 krill were then pooled before using $1 \mu \mathrm{g}$ from the RNA pool in the construction of each cDNA library. A Creator SMART cDNA library kit (Clontech) was used to construct the cDNA libraries in pDNR-LIB, which was then transformed into XL-1 Blue competent cells (Agilent Technologies) following manufacturer's instructions. Recombinant colonies were selected on Luria-Bertani agar medium with chloramphenicol. For each library, 960 individual colonies were manually picked into 96 well plates with $14 \%(\mathrm{w} / \mathrm{v})$ glycerol in Terrific Broth and chloramphenicol. These plates were then incubated overnight at $37^{\circ} \mathrm{C}$ before being stored at $-80^{\circ} \mathrm{C}$.

\section{Sequencing}

Initial sequencing of 96 clones from each of the cDNA libraries found more novel genes in the Peninsula winter library than in the South Georgia winter library, and so a further 768 clones were sequenced from the Peninsula winter library. This was later followed up by sequencing of a further 8 clones from the South Georgia winter cDNA library found to be differentially expressed in the microarray study. Sequencing was performed following procedures described in Seear et al. (2010). Sequence chromatograms were processed using Geneious 5.3 (Drummond et al. 2010) that trimmed vector, low quality sequence and 3'polyadenylate tails. All edited sequences $(\geq 80 \mathrm{bp})$ were submitted to dbEST and given the following accession numbers: dbEST, 75800160-75800881; GenBank, JK623235-JK623956.

\section{Microarray fabrication}

The microarray was populated with 4792 transcripts from krill caught in the summer from 2 latitudes $\left(55^{\circ} \mathrm{S}\right.$ and $\left.60^{\circ} \mathrm{S}\right)$ at various times of the day (Seear et al. 2010), along with 960 transcripts from krill caught during the winter at Peninsula $\left(62^{\circ} \mathrm{S}\right)$ and 960 transcripts from krill caught at South Georgia $\left(53.5^{\circ} \mathrm{S}\right)$ during the same winter. PCR amplification of clone inserts from the winter cDNAs, quality control and microarray printing were performed as described in Seear et al. (2010). In total, 13440 features were printed on the microarray, including 6712 clones from summer and winter krill cDNA libraries spotted in duplicate. Details of the microarray can be found at ArrayExpress (www.ebi.ac.uk/arrayexpress/) under accession number A-MEXP-2146.

\section{Challenging the microarray}

For the microarray hybridisations, total RNA was extracted as described for the cDNA library construction above. Double-stranded cDNA probes were then prepared using $500 \mathrm{ng}$ of total RNA as described in 
Petalidis et al. (2003). Hybridisation of labelled cDNA probes to the microarray was performed as described in Pura et al. (2008). Six biological replicates from each sample (Peninsula summer, Peninsula winter and South Georgia winter) were competitively hybridised against a reference pool of all samples used in the study. A dye swap was performed to check for cyanine fluor effects. Details from the microarray experiments performed here were submitted to ArrayExpress and assigned the accession number EMEXP-3453. Recording of microarray experiment metadata complies with minimum information about a microarray experiment (MIAME) guidelines.

\section{Microarray analysis}

Hybridised slides were scanned at $10 \mu \mathrm{m}$ resolution using a GenePix 4100 microarray scanner (MDS technologies). Image analysis and local background correction of spot intensities were performed with GenePix Pro 6.0 software (MDS technologies) as described in Seear et al. (2010). GenePix results files were then imported into GeneSpring GX 11.1 (Agilent Technologies) for all subsequent analyses. Normalisation was performed using a 'per spot and per chip' intensity dependent (Lowess) normalisation using software defaults (20\% smoothing/cutoff 10). Significant differential gene expression between Peninsula winter and Peninsula summer krill and between Peninsula winter and South Georgia winter krill was established by unpaired $t$-tests with Benjamini \& Hochberg's (1995) multiple test correction $(p<0.05)$ with only transcripts showing a 2 -fold or greater change in expression being presented in this study. Principal component analysis (PCA) was performed using GeneSpring GX 11.1 using the mean centering and scaling method.

\section{Expressed sequence tag assembly and annotation}

DNA sequences were matched to National Center for Biotechnology Information (NCBI) databases using the tools BLASTN, BLASTX and tBLASTX, and then annotated with Gene Ontology identifiers using the software Blast2GO (version 2.3.8; Conesa et al. 2005). Assemblies were generated with Geneious using a word length of 50, gap size of 1 and gap and mismatch errors of $5 \%$. The number of novel gene transcripts was estimated by assembling the results of our newly derived sequence assembly against the results of an assembly of all Euphausia superba ex- pressed sequence tags (ESTs) held within NCBI databases (6142 accessions) (De Pittà et al. 2008, Seear et al. 2009, Seear et al. 2010); assemblies were performed as described above using Geneious. Assembly results for ESTs showing notable patterns of differential expression were manually inspected to verify putative identities.

\section{Quantitative PCR}

Quantitative PCR was used to validate the microarray results on 4 transcripts indicated to be differentially expressed more than 2-fold between Peninsula winter and Peninsula summer krill and between Peninsula winter and South Georgia winter krill. Transcripts used in the Peninsula winter/summer qPCR comparison had significant sequence homology to trypsin (GenBank: GW422555), chymotrypsin (GenBank: GW423670), haemocyanin (GenBank: GW422778) and neuroparsin (GenBank: JK623718), while in the Peninsula winter/South Georgia winter comparison, trypsin and chymotrypsin were again used along with transcripts showing significant sequence homology to a fatty acid binding protein (GenBank: GW423585) and angiopoietin (GenBank: GW423168). These particular transcripts were chosen due to their importance in metabolism, oxygen transport, reproduction and blood vessel formation. Expression of each of the transcripts was normalised against a krill EST (GenBank: GW422811) with significant homology to triosephosphate isomerase (GenBank: ADD38004) that did not significantly change in expression between sample sites. Primers were designed around each of the 7 transcripts using Primer 3 (Rozen \& Skaletsky 2000) to generate PCR products of between 100 and 200 bp. Primer pair sequences are listed in Table 2.

The same total RNA samples used for the microarray experiments were also used for qPCR. One microgram of total RNA was used to make first strand cDNA using a Quantitect Reverse Transcription kit (Qiagen) that incorporated genomic DNA removal prior to reverse transcription. For each transcript of interest, cDNA from 3 individuals from each of the sample sites were run in duplicate qPCR reactions. Quantitative PCR was performed as described in Seear et al. (2010). Relative mean expression ratios were statistically compared between Peninsula winter and Peninsula summer and between Peninsula winter and South Georgia winter following normalisation against the reference gene using the relative expression software tool REST (Pfaffl et al. 2002). 
Table 2. Primer pair sequences used to generate PCR products

\begin{tabular}{|c|c|c|c|}
\hline Gene name & $\begin{array}{c}\text { Accession } \\
\text { number }\end{array}$ & Primer sequence $5^{\prime}-3^{\prime}$ & $\begin{array}{l}\text { Product } \\
\text { size (bp) }\end{array}$ \\
\hline \multirow[t]{2}{*}{ TPI } & \multirow[t]{2}{*}{ GW422811 } & F: TTC TGT CCG CAT CTT GTA CG & \multirow[t]{2}{*}{139} \\
\hline & & R: TTC CCA GGC ATT GAT GAT CT & \\
\hline \multirow[t]{2}{*}{ Neuroparsin } & \multirow[t]{2}{*}{ JK623718 } & F: CAG GCT GCA CCT AAC TGT GA & \multirow{2}{*}{112} \\
\hline & & R: CTG GAC CCT TAG CAC AGA CC & \\
\hline \multirow[t]{2}{*}{ Haemocyanin } & \multirow[t]{2}{*}{ GW422778 } & F: GCC TTC TTC CGT CTG CAT AA & \multirow[t]{2}{*}{105} \\
\hline & & R: CAA ATC CAC TCC TTC CCA AA & \\
\hline \multirow[t]{2}{*}{ Trypsin } & \multirow[t]{2}{*}{ GW422555 } & F: CAC TGT GTT GCT GGA GAG GA & \multirow[t]{2}{*}{ A 125} \\
\hline & & R: TCA TGC TGG ATG ATC TTG GA & \\
\hline \multirow[t]{2}{*}{ Chymotrypsin } & \multirow[t]{2}{*}{ GW423670 } & F: CAC CCA CGA GAA CTG GAA CT & \multirow[t]{2}{*}{ [ 103} \\
\hline & & R: CAG GCA TAC AGG CTG GAT CT & \\
\hline \multirow[t]{2}{*}{ Angiopoietin } & \multirow[t]{2}{*}{ GW423168 } & F: TGT GAT ATG GTG ACG GAT GG & \multirow{2}{*}{145} \\
\hline & & R: ACT CAT TGC CAA GCC AGA AC & \\
\hline \multirow{2}{*}{$\begin{array}{l}\text { Fatty acid } \\
\text { binding protein }\end{array}$} & \multirow[t]{2}{*}{ GW423585 } & F: GCA GAG ATG GGC CAG TCT AA & \multirow{2}{*}{ A 150} \\
\hline & & R: CTT TCC CAT TGG AGA GGT GA & \\
\hline
\end{tabular}

did not influence the South Georgia community because the nearest iceedges were more than $500 \mathrm{~km}$ from the sampling location.

\section{Microarray analysis}

The Antarctic krill cDNA microarray was used to compare the gene expression of Peninsula winter krill with Peninsula summer krill (seasonal comparison) and Peninsula winter krill with South Georgia winter krill (inter-location comparison). The seasonal comparison resulted in the largest number of transcripts that were differen-

\section{RESULTS}

\section{Environmental conditions at sampling sites}

There was about 2 to $3^{\circ} \mathrm{C}$ difference in SST between the winter and summer sampling campaigns at the Antarctic Peninsula, with typical temperatures of $-1.2^{\circ} \mathrm{C}$ in winter and $1.61^{\circ} \mathrm{C}$ in summer (Fig. 2). At South Georgia, SST temperatures at the sampling location were typically $0.0^{\circ} \mathrm{C}$. The nearest sea ice was less than $50 \mathrm{~km}$ from the winter sampling location at the Antarctic Peninsula but more than $200 \mathrm{~km}$ from the summer location (Fig. 3). Seasonal sea ice tially expressed 2-fold or more (false discovery rateadjusted $\mathrm{p}<0.05$ ) with 232 transcripts up-regulated and 41 transcripts down-regulated in the Peninsula summer relative to the Peninsula winter. Between overwintering locations, there were 109 transcripts up-regulated and 11 transcripts down-regulated in South Georgia winter relative to the Peninsula winter. Approximately $40 \%$ of all these differentially expressed transcripts could be identified through sequence matching to NCBI databases using BLAST. For each comparison, transcripts differentially expressed by more than 2-fold and successfully annotated through BLAST analysis ( $E$ [expect] value

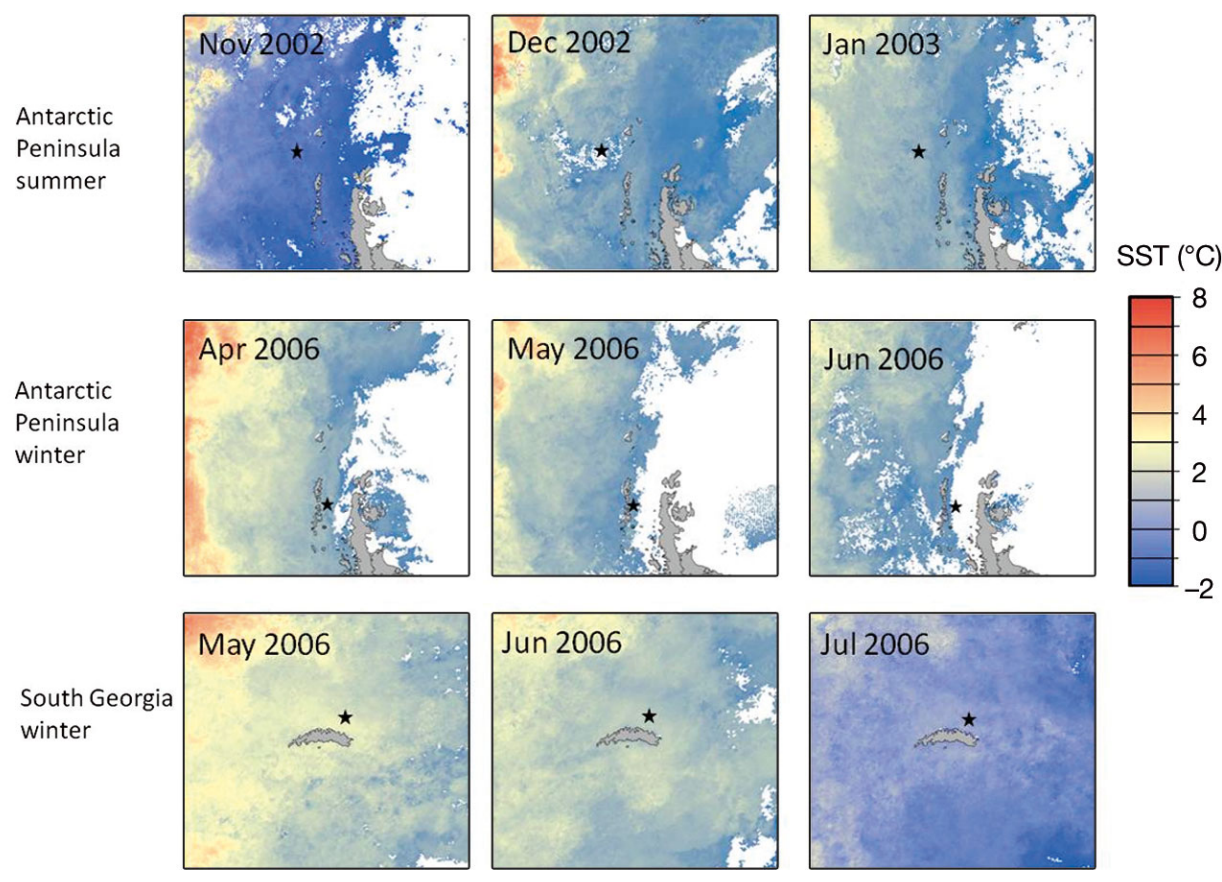

Fig. 2. Sea surface temperature (SST) during the month of sampling as well as the 2 preceding months for all 3 sampling locations. SST data were obtained from the JPL PODAAC POET service using data acquired by the Aqua MODIS instrument. Data were provided at a pixel resolution of $4 \mathrm{~km}$ and binned into monthly compo-sites. $\star$ : station locations 
Fig. 3. Sea ice concentration during the month of sampling and the 2 preceding months for the Peninsula summer and Peninsula winter samples. Plots are based on AMSR-E data provided by the University of Bremen, with a pixel spacing of $4 \mathrm{~km}$. Data were subsequently binned into monthly composites. Station locations are marked by a yellow star. South Georgia is not plotted given the observed lack of ice in the vicinity of the sampling location
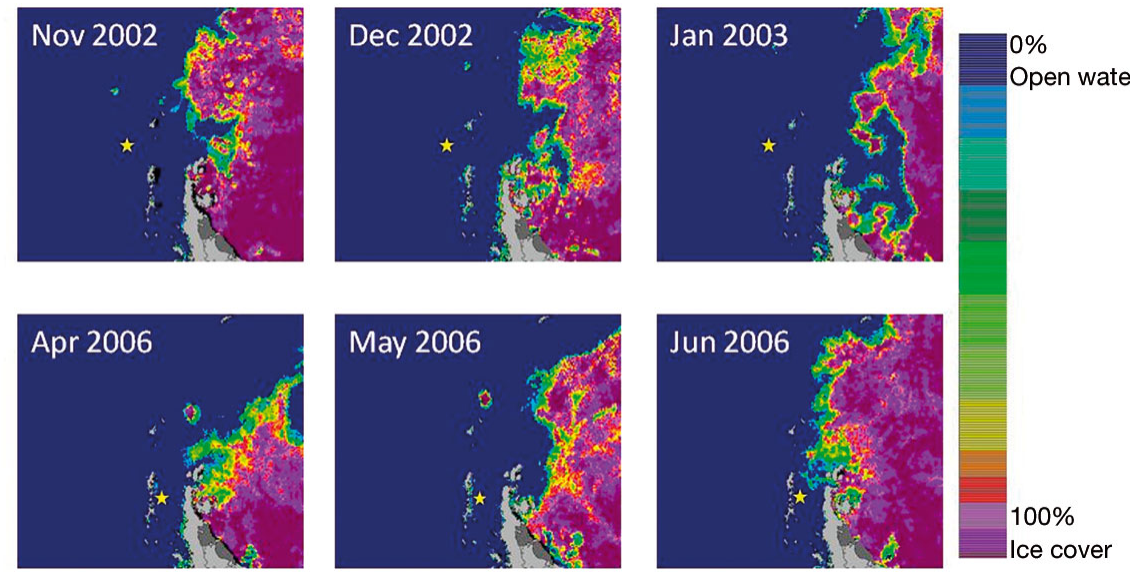

$<1 \times 10^{-6}$ ) are listed in Tables S1 to S4 in the supplement at www.int-res.com/articles/suppl/m467 p061_supp.pdf, in order of fold change with respective BLASTX hits, contig/singleton ID and Gene ontology annotation. The $M$ versus $A$ plot in Fig. 4A indicates that all differentially expressed genes were highly expressed with an average signal intensity ( $A$ value) greater than 9. Principal component analysis (PCA) clearly discriminated between Peninsula winter and summer samples, but there was considerable overlap of the South Georgia sample with both Peninsula samples (Fig. 4B).
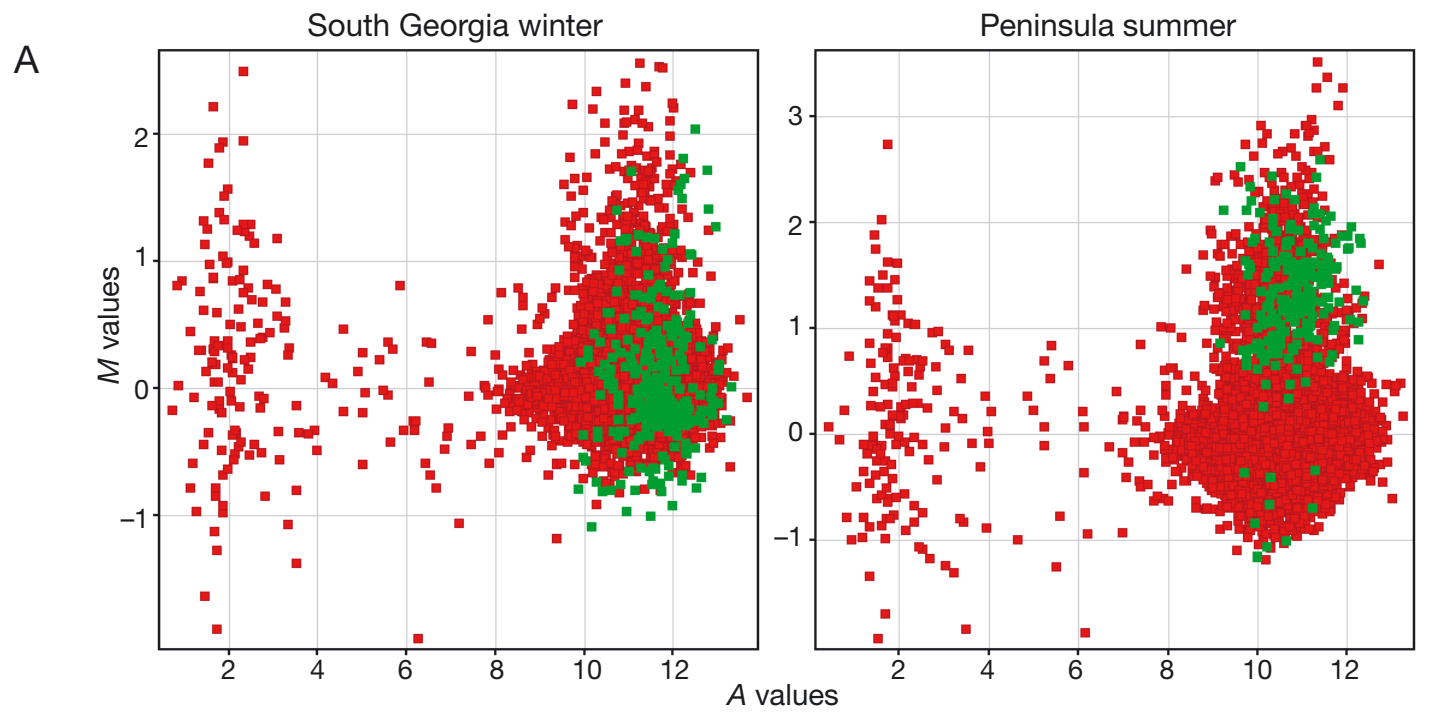

Fig. 4. (A) $M$ versus $A$ expression scatter plots of all the genes represented on the microarray in Peninsula summer and South Georgia winter samples relative to the pooled reference. Each square represents an average of all 6 replicates in each sample. $M=\log _{2}$ fold change of Lowess normalised spot intensities between sample and the pooled reference; $A=$ average signal intensity. Significantly differentially expressed genes (unpaired $t$-tests, $\mathrm{p}<$ 0.05) between Peninsula winter and each sample are indicated by the green squares. (B) Principal component analysis (PCA) of normalised gene expression levels for season and location. The $x, y$ and $z$ axes, representing the first 3 components, accounted for $95 \%$ of the data variance. Apart from one outlier, PCA discriminates between summer and winter in the Peninsula, but no such discrimination can be seen with the South Georgia winter sample

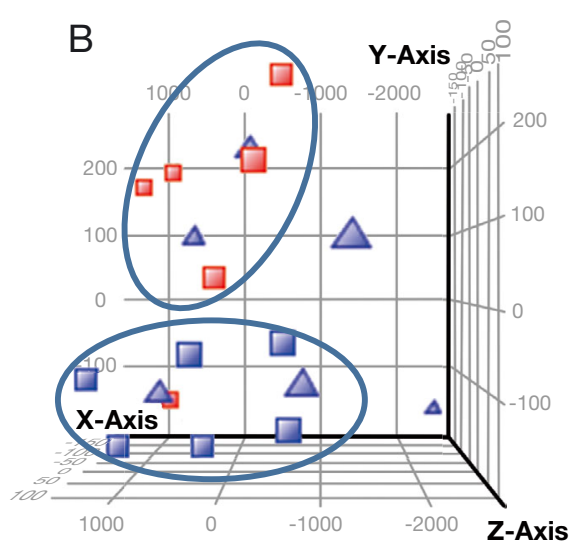

Legend-3D PCA Scores

Colour by Season

Summer

Winter

Shape by Location $\square$ Peninsula

$\triangle$ South Georgia 


\section{Quantitative PCR}

Quantitative PCR was used to validate the differential expression of 4 transcripts in the Peninsula summer samples and 4 transcripts in the South Georgia winter samples relative to Peninsula winter samples (Fig. 5). All transcripts were regulated in the same direction as on the microarray, with all 4 transcripts in the Peninsula summer and 1 out of the 4 transcripts in the South Georgia winter significantly differentially expressed ( $p<0.05)$. There were some differences between the level of fold change between the microarray and the qPCR analyses. For individual genes, differences in the fold change of differential expression shown by microarray versus qPCR analyses are reported in a number of other studies (e.g. Mukai et al. 2009, Sanogo et al. 2011)
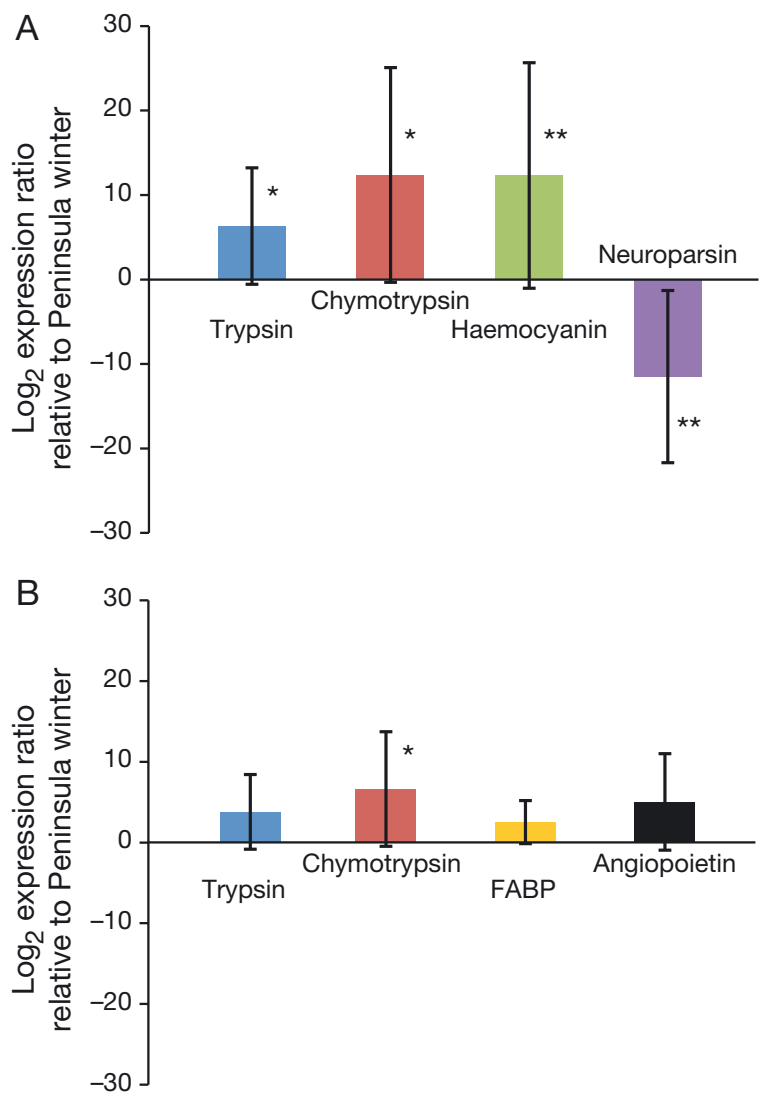

Fig. 5. Quantitative PCR (qPCR) expression profiles of 4 genes differentially expressed (A) between Peninsula winter and Peninsula summer samples and (B) between Peninsula winter and South Georgia winter samples. The analysis was performed to cross-validate with the expression profiles derived from microarray analysis. The choice of transcripts was made based on their functional importance to krill physiological processes. All transcripts analysed by qPCR were regulated in the same direction as in the microarray analysis, although there was some variance in exact fold change levels and may result from misidentification of gene homologues with the separate isoforms having varying levels of expression, or may be due to different detection thresholds for the 2 techniques. Nevertheless, 5 of the 8 transcripts were successfully validated by qPCR, with the remaining 3 differentially expressed in the same direction.

\section{DISCUSSION}

Seasonal changes in the physiology and behaviour of Antarctic krill have been reported extensively over the past $20 \mathrm{yr}$, but our understanding of the controlling factors in this seasonal transition are only at an early stage (Meyer et al. 2010, Meyer 2012). The present study represents a preliminary look at the potential molecular mechanisms involved in seasonal change, in that it considers just 2 sampling regions at 2 points in the seasonal cycle, with the comparison limited to a single sexual stage (female immature adults). Nevertheless, this study does show clear examples of how physiological changes can be observed at the level of mRNA transcription from genes, indicating that this is a key step in controlling seasonal physiological change. We used microarray analysis coupled with qPCR to compare mRNA expression between different sets of krill to examine the effect of season and location on gene expression.

In order to relate changes in gene expression to the physiological status of krill, we were limited to describing only those genes that could be assigned putative functional roles through sequence matching. This amounted to ca. $40 \%$ of the differentially expressed transcripts identified using the microarray. By comparision, studies on the environmental regulation of gene expression in the model crustacean species Daphnia pulex (Colbourne et al. 2011) are similarly limited by a paucity of crustacean gene function reference data. Further work is needed to demonstrate the function of crustacean transcripts that correspond with environmental change, e.g. through mutational studies, gene knock outs and protein knock down by RNAi. Notwithstanding the limitation that our results cover only a subset of all genes that may be differentially expressed between seasons and locations, it is instructive to consider data generated by multi-gene analysis, because they allow us to comment on earlier studies and suggest avenues for subsequent investigation (MacRae 2010).

Many significant changes in gene expression were observed between winter and summer at the Peninsula. These differences may be part of a wider global 
shift in gene expression, as the PCA (Fig. 4B) showed the gene expression levels of Peninsula winter krill to cluster separately from those of Peninsula summer. This global shift in gene expression supports the idea of krill undergoing a fundamental switch to a different physiological state (Meyer et al. 2002, Meyer 2012). Conversely, despite a number of genes found to be differentially expressed between South Georgia winter and Peninsula winter, PCA could not discriminate South Georgia from the other 2 samples. This may indicate that krill in the winter at South Georgia share similar characteristics of both summer and winter krill in the Peninsula (at least in their gene expression).

\section{Seasonal changes in gene expression}

We found evidence of significant changes in gene expression between summer and winter in a number of major biological functions performed by Antarctic krill. In the following section, we examine these functions and the evidence from our gene expression analyses for seasonal modulation.

Feeding and digestion

We found that transcript levels of both trypsin and chymotrypsin were down-regulated during the winter period compared to summer. Trypsin possesses 2 main functions: hydrolysis of food protein and activation of zymogens of trypsin and other digestive proteases (Muhlia-Almazán et al. 2008). In terms of the latter, trypsin activation is the first step in a series of consecutive reactions, where the function of multiple proteinases of different classes is part of a coordinated physiological process, such as the digestion of food protein. Organisms that have multiple classes of proteinases, such as trypsin and chymotrypsin, can enhance hydrolysis of food protein, and so increase the efficient use of food protein.

Morris \& Priddle (1984) found that the amount of food in alimentary tracts decreases during winter, and suggested this was a function of both the level of feeding activity and the availability of food. Satellite observations do not provide sufficient coverage of the sample site to determine chl a biomass in the water column at the time of sampling. However, the sampling sites were in open water in both summer and winter, and Quetin et al. (2003) found that open water phytoplankton levels around the Peninsula region were substantially lower in the winter com- pared to summer. The lack of available food is therefore likely to be reflected in the down-regulation of genes for digestive enzymes. For instance, Saborowski \& Buchholz (1999) showed that, in starving Euphausia superba, digestive enzyme activity rapidly decreases in the stomach and, to a lesser extent, the midgut gland. Activities recover again after prolonged advanced starvation of several days, but not to initial values.

Trypsin may also be the activator of enzymes involved in the degradation of cuticle, such as $\beta-\mathrm{N}-$ acetylglucosaminidase, present in the moulting fluid of insects (Samuels et al. 1993) and crustaceans (Warner \& Matheson 1998). Klein et al. (1996) found that both trypsin mRNA and trypsin enzyme activity are at their highest levels during premoult (stage D1) of the shrimp Penaeus vannamei. In Antarctic krill, Seear et al. (2010) found trypsin to be up-regulated more than 4 -fold during premoult. Nevertheless, the present study limited the dataset only to moult-stage $\mathrm{C}$ individuals, meaning that any differential expression of trypsin is unlikely to be related to the moult cycle.

\section{Reproduction}

In arthropods, there is accumulating evidence that peptide hormones such as insulin-related peptides (IRPs) and neuroparsins (NPs) play a crucial role in female reproductive physiology (Badisco et al. 2011). The first NP was identified from the migratory locust Locusta migratoria as an antigonadotropic factor that delayed vitellogenesis (Girardie et al. 1987a,b). Insulin-related peptides have an opposite effect on reproductive physiology and promote reproductive development (Badisco et al. 2011). IRPs and NPs have since been identified in a number of arthropods, including the crab Carcinus maenas and the lobster Homarus americanus (Towle \& Smith 2006). In the present study, we found down-regulation of NP in summer alongside an up-regulation of IRP. Combined, this is likely to have a positive effect on reproductive physiology, particularly vitellogenesis.

An interesting aspect of the use of these genes in the control of reproductive maturation is their further link to nutritional status. Female fruit flies, for example, require an intact insulin-signalling pathway in order to regulate egg production as a function of their nutritional status (Drummond-Barbosa \& Spradling 2001). Direct links between nutritional condition and vitellogenesis were described in Antarctic krill by Cuzin-Roudy \& Labat (1992), who found that ovarian 
maturity levels correspond to the timing of ice-edge blooms. Likewise, Schmidt et al. (2012) found that reproductive maturation is achieved earlier in Antarctic krill exposed to early spring blooms. In that respect, Antarctic krill can be considered an income breeder that relies on feeding, rather than stored reserves, to fuel the spring reproductive effort (Hagen et al. 1996). The NP and IRP signalling pathways likely play an important role in this reproductive strategy in regulating the onset of vitellogenesis. A food-based signalling pathway is likely to work alongside other pathways, such as those responsive to the light regime, given other evidence on the sensitivity of maturation processes to perturbed light-regime patterns (Hirano et al. 2003, Teschke et al. 2008).

\section{Respiration}

As in some other crustaceans and molluscs, krill use the copper-based haemocyanin as their extracellular respiratory pigment (Brix et al. 1989, Spicer \& Strömberg 2002). We found that levels of haemocyanin gene expression were considerably lower during winter compared to summer. A lower haemocyanin concentration in the haemolymph will result in a reduced capacity to transport oxygen (Bridges et al. 1983), particularly to peripheral tissues such as the swimming muscles, appendages and digestive organs. This would also be reflected in lower overall levels of respiration.

Lower winter respiration levels in Antarctic krill are reported in a number of studies. Kawaguchi et al. (1986) showed that, in krill wintering under fast ice in Lutzow-Holm Bay, oxygen consumption in August is half that in September. Quetin \& Ross (1991) found that post juvenile krill ( 30 to $55 \mathrm{~mm}$ ) from the Bransfield Strait have winter respiration rates that are only one-third of those measured in summer. RakusaSuszczewski (1990) reported that the oxygen consumption in Admirality Bay, King George Island, increases by $40 \%$ in early spring between early October $\left(-1.8^{\circ} \mathrm{C}\right)$ and late November $\left(-1.0^{\circ} \mathrm{C}\right)$. In the Lazarev Sea, Meyer et al. (2010) found that, compared to spring, oxygen uptake rates in krill are reduced by $50 \%$ in autumn and by $70 \%$ in winter. Our findings do not permit a quantitative assessment of the level of oxygen transport, which must also take into account further factors such the diffusivity of oxygen within the haemocyanin and the rate of arterial pumping (Bridges et al. 1983, Spicer \& Strömberg 2002). Haemocyanin may also have additional physiological roles, such as short-term starvation tolerance
(Spicer \& Strömberg 2002) and immunity function (see below). Nevertheless, the down-regulation of haemocyanin gene expression in winter is consistent with observations of reduced respiration rate at this time of year.

\section{Motor activity}

Krill are highly active animals and can generate considerable propulsion through powerful swimming legs (pleopods) and the rapid contraction of abdominal muscles (Kils 1981). We found a summertime upregulation of numerous genes involved in the maintenance of muscular activity, such as beta actin, arginine kinase, myosin light chain and sarcoplasmic calcium-binding protein. The up-regulation of these genes indicates that these muscles are used to a greater extent during the summer. In turn, this suggests that krill have a higher level of activity in summer than in winter.

Although it is widely accepted that krill exhibit lower metabolic rates in winter compared to summer (see above), the cause of this metabolic depression is less clear. Ikeda \& Dixon (1982) showed that starvation alone can cause metabolic rates to decrease by almost $40 \%$, implying that low food availability is a sufficient explanation for this depression. However, experiments on krill in autumn and winter (e.g. Atkinson \& Snyder 1997, Atkinson et al. 2002) report no increase in feeding rates when exposed to enhanced food levels, suggesting that the krill were in a quiescent state. Meyer et al. (2010) posited that entry into and exit from quiescence is triggered by the photoperiod or light level. This is supported by incubation experiments, such as those by Teschke et al. $(2007,2008)$, where krill exposed to wintertime photoperiods showed a decrease in metabolic rate and a failure to mature. Furthermore, Seear et al. (2009) found a down-regulation of myosin when krill were exposed to a winter photoperiod for $7 \mathrm{~d}$, suggesting that krill are less active in winter. The present study makes a similar finding, but within a freshly captured wild krill population. Together, these results indicate that wintertime metabolic depression is accompanied by lower activity levels. If seasonal metabolic depression were simply a matter of specific dynamic activity in terms of feeding and digestion, it is likely that muscle use would be similar year-round, since foraging for patches of food would need to continue. The present results are otherwise consistent with krill entering a winter quiescent state, where foraging decreases and the level of muscular activity becomes reduced. 
Immune function

We found 2 major immune gene types were upregulated in summer: cathepsins ( $\mathrm{C}$ and $\mathrm{K}$ ) and $\mathrm{C}$ type lectins. Cathepsins belong to the cysteine protease family, are localized in the lysosomes and endosomes, and degrade intracellular or endocytosed proteins (Pongsomboon et al. 2008a). They also have an additional role as agents of apoptosis (programmed cell death) (Pongsomboon et al. 2008a). Ctype lectins contribute to innate immune responses in invertebrates including prophenoloxidase activation, enhancement of encapsulation, nodule formation of hemocytes, opsonin formation, antibacterial activity, antifungal activity and injury healing (Cerenius et al. 2010). This is the first study to report the expression of these genes in any euphausiid species. Most of what is known in terms of immune function in crustaceans derives from studies of diseases of commercially-reared shrimps such as Penaeus monodon and Fenneropenaeus chinensis. Pongsomboon et al. (2008b) found that shrimps up-regulated both C-type lectin and cathepsin L-like cysteine peptidases when infected with yellow head virus. A similar response was observed upon infection with white spot syndrome virus (WSSV) (Aoki et al. 2011).

Haemocyanin may also be an additional contributor to the krill immune system given that, in addition to being an oxygen carrier, it is known to be an antiviral, antibacterial and antifungal protein. In Fenneropenaeus chinensis, for instance, Wang et al. (2006) found that haemocyanin expression was upregulated in individuals infected with the bacteria Vibrio anguillarum (heat killed for the purpose of the experiment). Furthermore, WSSV was seen to interfere with haemocyanin expression, potentially as a means of depressing the immune response in order to complete its own life-cycle.

The up-regulation of immune function genes in summer probably reflects the seasonal abundance cycle of microbial pathogens such as ciliates, bacteria and viruses. For instance, in a study of the microbial community near the South Orkney islands, Clarke \& Leakey (1996) found up to a 10-fold increase in bacterial carbon and a 6 -fold increase in ciliates during the summer. However, viruses have less of a seasonal abundance pattern (Guixa-Boixereu et al. 2002). So far the main diseases reported in euphausiid species are from bacterial pathogens (Miwa et al. 2008) or ciliates (Gómez-Gutiérrez et al. 2003, 2006, 2010). It is likely that the immune response will be similar whatever the agent of infection given that, as an invertebrate, krill possess a non-adaptive immune system.

\section{Spatial differences in overwintering gene expression}

\author{
Feeding and digestion
}

A number of genes were found to be differentially expressed between the Peninsula winter and South Georgia winter krill populations. One of the largest fold differences was in the expression of trypsin and trypsin-like serine protease, in which expression levels were around 3 times higher at South Georgia. As discussed above, serine proteases are principally involved in the hydrolysis of food protein. Their upregulation in the South Georgia population suggests that levels of feeding activity are higher there than at the Peninsula during the winter period.

Across the suite of up-regulated transcripts, genes involved in proteolysis accounted for more than half of those most highly up-regulated at South Georgia. Alongside trypsin and trypsin-like serine protease, these included various transcripts of carboxypeptidase B and chymotrypsin. Compared with lipids, proteins play a minor role as an energy reserve in krill for overwintering, with around only $3 \%$ of body protein being used up each month during the winter months (Meyer et al. 2010, Meyer 2012). However, protein metabolism is recognised as having a much more significant role in energy turnover during the summer (Meyer 2012). The greater prominence of proteolytic genes in the winter population of South Georgia suggests that those krill are feeding in a similar way to summer populations elsewhere. The semipermanent phytoplankton bloom around South Georgia is one of the largest in the Southern Ocean (Park et al. 2010) and is likely to produce a considerable flux of carbon-rich sediment to the benthos (Whitehouse et al. 2012). Schmidt et al. (2011) describe how Antarctic krill frequent benthic habitats year-round, and that krill caught in upper waters retain signals of benthic feeding, suggesting frequent and dynamic exchange between surface and seabed. Although krill are also found in benthic habitats at the Peninsula (Clarke \& Tyler 2008), comparatively lower levels of productivity in the upper water column may mean that such habitats are less profitable food banks.

\section{Reproduction}

There were no indications of any significant difference in the expression of transcripts of the peptide hormones NP or IRP, indicating that vitellogenesis is being repressed to similar levels in both South Geor- 
gia and the Antarctic Peninsula during winter. Nevertheless, there were indications that South Georgia krill were already making preparations for the future reproductive effort in their up-regulation of a fatty acid binding protein (FABP). FABPs are small (14 to $15 \mathrm{kDa}$ ) cytosolic proteins that play a role in intracellular targeting of fatty acids to specific organelles and metabolic pathways, and the protection of cellular structures from the detergent effects of fatty acids (Ho et al. 2002, Storch et al. 2002, Córsico et al. 2004, Esteves \& Ehrlich 2006). In the Chinese mitten crab Eriocheir sinensis, Gong et al. (2010) found that these molecules play an important role in the transport of lipids during ovarian development. In the present instance, vitellogenesis has yet to take place, but the up-regulation of these genes may be a necessary precursor to reproductive development in the spring.

The possibility that South Georgia krill make wintertime preparations for vitellogenesis, whereas Antarctic Peninsula krill do not, indicates that there is likely to be an underlying difference in their respective lipid reserves. The ability of South Georgia krill to feed during winter means that they have a lower requirement to use stored lipids to fuel metabolism, as is the case in more southerly populations (Hagen et al. 1996). This in turn means that there is more lipid available to invest in ovarian development prior to the onset of spring blooms. Nevertheless, the observation that peptide hormone expression does not differ significantly between the 2 environments during winter means that further elements must also be in place before the commencement of vitellogenesis. For instance, Brown et al. (2011) demonstrated that krill can alter the timing of their maturation according to the prevailing light regime, implying that appropriate photoperiods and light intensities may also be necessary to facilitate ovarian maturation.

\section{Immune function}

Four types of cathepsin transcripts were up-regulated in South Georgia winter krill: cathepsin L2, C, $\mathrm{K}$ and cathepsin d-like protein. All the above cathepsins are likely to be localised in lysosomes with an immune function to degrade intracellular or endocytosed proteins. The up-regulation of i-type lysozymelike protein 1 probably assists in this process. This result suggests that the threat of infection faced by South Georgia Antarctic krill in winter is of the same magnitude as that faced by Antarctic Peninsula krill in summer. Therefore, not only are the infective agent populations seasonally modulated, they are also likely to be responsive to latitudinal clines in environmental factors such as temperature. At the Antarctic Peninsula, winter temperatures were below $0^{\circ} \mathrm{C}$, whereas they largely remained at or above $0^{\circ} \mathrm{C}$ year-round at South Georgia. It is likely that many disease agents are unable to exist below freezing point, but they may otherwise survive, infect and lead to disease above such temperatures. This means that the threat of infection will be higher at South Georgia at all times of year and may represent one of the major causes of mortality during the summer months. The present study gives a rather limited insight into this field but does indicate the value of further studies into relative rates of infection across krill habitats.

\section{Motor activity and respiration}

There was no evidence that the expression of genes associated with motor activity (myosin, betaactin) or respiration (haemocyanin) were differentially expressed between the winter time populations at South Georgia and the Antarctic Peninsula. Therefore, although South Georgia krill appear to have greater feeding success during winter, fuelling growth and reproductive development, levels of activity in the 2 environments appear to be similar during this time. This would suggest that both populations of krill are undergoing a phase of physiological quiescence, despite the different prevailing environmental conditions and light regimes. This does not diminish the importance of external cues in synchronising seasonal cycles in krill, but does suggest that krill may be able to adjust to local conditions when coordinating their life-cycle phases (Brown et al. 2011). Such flexibility indicates that there is likely to be a hierarchy of internal as well as external signals used to control these phases. The similarities in wintertime gene expression patterns for activity and respiration at South Georgia and the Peninsula observed in the present study further testify to the ability of krill to adapt to the wide range of conditions that prevail within the Southern Ocean.

\section{CONCLUSIONS}

The present study is limited in scope, in that it considers just 2 locations and just 1 sex within a specific maturity stage. There is undoubtedly much to be gained from extending the remit of such comparative 
expression analyses to further locations (encompassing populations associated with sea ice or shelf environments), other times of the year (such as transition periods between winter and summer phases), and other developmental stages (e.g. males and larvae). Nevertheless, this study provides a degree of validation at the molecular level to some of the seasonal physiological differences noted at the level of the whole organism. In particular, seasonal alteration in respiration rates were observed in the differential expression of the oxygen carrier haemocyanin, while a summertime up-regulation of motor genes such as myosin and beta actin is consistent with higher levels of activity noted at that time of year (Quetin et al. 1994). A comparison between locations is also informative in showing that overwintering physiology may differ in some respects but remain similar in others. For instance, feeding, digestion and reproductive preparations occurred at a higher level during winter at South Georgia compared to the Antarctic Peninsula. Nevertheless, these differences appear to be achieved without any notable differences in the molecular expression of genes associated with respiration or activity. A further advantage of the present approach is that all physiological processes were examined equally, with selection based purely on whether levels of molecular expression differed between populations. This allowed further seasonally- and spatiallyimportant processes to be identified that previous studies have not addressed, most notably the expression of genes associated with immune function. Overall, this study shows that krill physiology is seasonally modulated at the molecular level, and that the degree of modulation is spatially flexible according to prevailing environmental conditions. Future molecular studies into seasonal changes in krill physiology would likely benefit from improvements to the measurement of gene expression, such as the use of oligonucleotide arrays. However, the use of a technology such as RNA-Seq to measure gene expression is very problematic due to the lack of a fully sequenced $\mathrm{Eu}$ phausia superba reference genome; furthermore, full sequencing is not likely in the near future due to the large genome size (Jeffery 2012).

Acknowledgements. We thank the captain, crew and scientists of the RRV 'James Clark Ross' during the JR82 cruise as well as those aboard the MV 'Saga Sea' for the capture, preservation and provision of Antarctic krill. K. Schmidt provided invaluable help in curating the krill and in providing advice on their analysis. G. Hillyard assisted with PCR amplification of microarray clones. This study was carried out as part of the Ecosystems programme at the British Antarctic Survey (Natural Environment Research Council).

\section{LITERATURE CITED}

Aoki T, Wang HC, Unajak S, Santos MD, Kondo H, Hirono I (2011) Microarray analyses of shrimp immune responses. Mar Biotechnol (NY) 13:629-638

Atkinson A, Snyder R (1997) Krill-copepod interactions at South Georgia, Antarctica, I. Omnivory by Euphausia superba. Mar Ecol Prog Ser 160:63-76

Atkinson A, Meyer B, Stubing D, Hagen W, Schmidt K, Bathmann UV (2002) Feeding and energy budgets of Antarctic krill Euphausia superba at the onset of winterII. Juveniles and adults. Limnol Oceanogr 47:953-966

Atkinson A, Siegel V, Pakhomov EA, Jessopp MJ, Loeb V (2009) A re-appraisal of the total biomass and annual production of Antarctic krill. Deep-Sea Res I 56:727-740

Badisco L, Marchal E, Wielendaele PV, Verlinden $H$, Vleugels R, Broeck JV (2011) RNA interference of insulin-related peptide and neuroparsins affects vitellogenesis in the desert locust Schistocerca gregaria. Peptides 32:573-580

Benjamini Y, Hochberg Y (1995) Controlling the false discovery rate: a practical and powerful approach to multiple testing. J R Stat Soc B 57:289-300

Boyd CM, Heyraud M, Boyd CN (1984) Feeding of the Antarctic krill Euphausia superba. J Crustac Biol 4: 123-141

Bridges C, Savel A, Stöcker W, Markl J, Linzen B (1983) Structure and function of krill (Euphausia superba) haemocyanin-adaptation to life at low temperature. Life Chem Rep Suppl 1:353-356

Brix O, Borgund S, Barnung T, Colosimo A, Giardina B (1989) Endothermic oxygenation of hemocyanin in the krill Meganyctiphanes norvegica. FEBS Lett 247:177-180

Brown M, Kawaguchi S, King R, Virtue P, Nicol S (2011) Flexible adaptation of the seasonal krill maturity cycle in the laboratory. J Plankton Res 33:821-826

Buchholz F (1982) Drach's moult staging system adapted for euphausiids. Mar Biol 66:301-305

CCAMLR (Commission for the conservation of Antarctic marine living resources) (2010) Statistical bulletin. CCAMLR, Hobart

Cerenius L, Jiravanichpaisal P, Liu HP, Soderhall I (2010) Crustacean immunity. In: Soderhall K (ed) Invertebrate immunity, Book 708. Springer-Verlag, Berlin, p 239-259

Clark MS, Thorne MAS, Toullec JY, Meng Y, Guan LL, Peck LS, Moore S (2011) Antarctic krill 454 pyrosequencing reveals chaperone and stress transcriptome. PLoS ONE 6:e15919

Clarke A, Leakey RJG (1996) The seasonal cycle of phytoplankton, macronutrients, and the microbial community in a nearshore Antarctic marine ecosystem. Limnol Oceanogr 41:1281-1294

> Clarke A, Morris DJ (1983) Towards an energy budget for krill: the physiology and biochemistry of Euphausia superba Dana. Polar Biol 2:69-86

> Clarke A, Tyler PA (2008) Adult Antarctic krill feeding at abyssal depths. Curr Biol 18:282-285

- Colbourne JK, Pfrender ME, Gilbert D, Thomas WK and others (2011) The ecoresponsive genome of Daphnia pulex. Science 331:555-561

- Conesa A, Gotz S, Garcia-Gomez JM, Terol J, Talon M, Robles M (2005) Blast2GO: a universal tool for annotation, visualization and analysis in functional genomics research. Bioinformatics 21:3674-3676

> Córsico B, Liou HL, Storch J (2004) The alphahelical domain 
of liver fatty acid binding proteins responsible for the diffusion-mediated transfer of fatty acids to phospholipid membranes. Biochemistry 43:3600-3607

Croxall JP, Nicol S (2004) Management of Southern Ocean fisheries: global forces and future sustainability. Antarct Sci 16:569-584

Cullen M, Kaufmann RS, Lowery MS (2003) Seasonal variation in biochemical indicators of physiological status in Euphausia superba from Port Foster, Deception Island, Antarctica. Deep-Sea Res II 50:1787-1798

Cuzin-Roudy J, Labat JP (1992) Early summer distribution of Antarctic krill sexual development in the Scotia-Weddell region: a multivariate approach. Polar Biol 12:65-74

> De Pittà C, Bertolucci C, Mazzotta GM, Bernante F and others (2008) Systematic sequencing of mRNA from the Antarctic krill (Euphausia superba) and first tissue specific transcriptional signature. BMC Genomics 9:45

Drummond AJ, Ashton B, Buxton S, Cheung M and others (2010) Geneious 5.3. Available at www.geneious.com/

> Drummond-Barbosa D, Spradling AC (2001) Stem cells and their progeny respond to nutritional changes during Drosophila oogenesis. Dev Biol 231:265-278

El-Sayed SZ (1988) Seasonal and interannual variabilities in Antarctic phytoplankton with reference to krill distribution. In: Sahrhage D (ed) Antarctic ocean resources and variability. Springer-Verlag, Heidelberg, p 101-119

Esteves A, Ehrlich R (2006) Invertebrate intracellular fatty acid binding proteins. Comp Biochem Physiol C Toxicol Pharmacol 142:262-274

Feder ME, Hofmann GE (1999) Heat-shock proteins, molecular chaperones, and the stress response: evolutionary and ecological physiology. Annu Rev Physiol 61:243-282

> Girardie J, Boureme D, Couillaud F, Tamarelle M, Girardie A (1987a) Anti-juvenile effect of neuroparsin-A, a neuroparsin isolated from locust corpora cardiaca. Insect Biochem 17:977-983

Girardie J, Bourême D, Girardie A (1987b) Production sites of the three neuroparsin proteins characterized of the corpora cardiaca of the migratory locust. Insect Biochem 17:29-36

- Gómez-Gutiérrez J, Peterson WT, Derobertis A, Brodeur RD (2003) Mass mortality of krill caused by parasitoid ciliates. Science 301:339

Gómez-Gutiérrez J, Peterson WT, Morado JF (2006) Discovery of a ciliate parasitoid of euphausiids off Oregon, USA: Collinia oregonensis n. sp. (Apostomatida: Colliniidae). Dis Aquat Org 71:33-49

Gómez-Gutiérrez J, Robinson CJ, Kawaguchi S, Nicol S (2010) Parasite diversity of Nyctiphanes simplex and Nematoscelis difficilis (Crustacea: Euphausiacea) along the northwestern coast of Mexico. Dis Aquat Org 88: 249-266

> Gong YN, Li WW, Sun JL, Ren F, He L, Jiang H, Wang Q (2010) Molecular cloning and tissue expression of the fatty acid-binding protein (Es-FABP) gene in female Chinese mitten crab (Eriocheir sinensis). BMC Mol Biol 11:71

Guixa-Boixereu N, Vaque D, Gasol JM, Sanchez-Camara J, Pedros-Alio C (2002) Viral distribution and activity in Antarctic waters. Deep-Sea Res II 49:827-845

Hagen W, VanVleet ES, Kattner G (1996) Seasonal lipid storage as overwintering strategy of Antarctic krill. Mar Ecol Prog Ser 134:85-89

> Hirano Y, Matsuda T, Kawaguchi S (2003) Breeding Antarctic krill in captivity. Mar Freshwat Behav Physiol 36: 259-269
Ho SY, Delgado L, Storch J (2002) Monoacylglycerol metabolism in human intestinal Caco-2 cells: evidence for metabolic compartmentation and hydrolysis. J Biol Chem 277:1816-1823

Ikeda T, Dixon P (1982) Body shrinkage as a possible overwintering mechanism of the Antarctic krill, Euphausia superba Dana. J Exp Mar Biol Ecol 62:143-151

Jeffery NW (2012) The first genome size estimates for six species of krill (Malocostraca, Euphausiidae): large genomes at the north and south poles. Polar Biol 35: 959-962

Kawaguchi K, Ishikawa S, Matsuda O (1986) The overwintering of Antarctic krill (Euphausia superba Dana) under the coastal fast ice off the Ongul Islands in Lutzow-Holm Bay, Antarctica. Mem Natl Inst Polar Res 44 (Spec Issue): $67-85$

Kils U (1981) Swimming behaviour, swimming performance and energy balance of Antarctic krill Euphausia superba. BIOMASS Sci Ser 3, SCAR, Cambridge

Klein B, LeMoullac G, Sellos D, VanWormhoudt A (1996) Molecular cloning and sequencing of trypsin cDNAs from Penaeus vannamei (Crustacea, Decapoda): use in assessing gene expression during the moult cycle. Int $\mathrm{J}$ Biochem Cell Biol 28:551-563

Laws RM (1985) The ecology of the Southern Ocean. Am Sci 73:26-40

Lenz PH, Unal E, Hassett RP, Smith CM, Bucklin A, Christie AE, Towle DW (2012) Functional genomics resources for the North Atlantic copepod, Calanus finmarchicus: EST database and physiological microarray. Comp Biochem Physiol Part D Genomics Proteomics 7:110-123

> MacRae TH (2010) Gene expression, metabolic regulation and stress tolerance during diapause. Cell Mol Life Sci 67:2405-2424

Makarov RR, Denys CJ (1980) Stages of sexual maturity of Euphausia superba, Vol 11. BIOMASS Handbook, Scientific Committee on Antarctic Research, Cambridge, UK

Meyer B (2012) The overwintering of Antarctic krill, Euphausia superba, from an ecophysiological perspective. Polar Biol 35:15-37

Meyer B, Atkinson A, Stubing D, Oettl B, Hagen W, Bathmann UV (2002) Feeding and energy budgets of Antarctic krill Euphausia superba at the onset of winter - I. Furcilia III larvae. Limnol Oceanogr 47:943-952

> Meyer B, Auerswald L, Siegel V, Spahic S and others (2010) Seasonal variation in body composition, metabolic activity, feeding, and growth of adult krill Euphausia superba in the Lazarev Sea. Mar Ecol Prog Ser 398:1-18

> Miwa S, Kamaishi T, Matsuyama T, Hayashi T, Naganobu M (2008) Histopathology of Antarctic krill, Euphausia superba, bearing black spots. J Invertebr Pathol 98: 280-286

Morris DJ, Priddle J (1984) Observations on the feeding and moulting of the Antarctic krill, Euphausia superba. Br Antarct Surv Bull 65:57-63

Muhlia-Almazán A, Sanchez-Paz A, Garcia-Carreno FL (2008) Invertebrate trypsins: a review. J Comp Physiol B 178:655-672

> Mukai M, Replogle K, Drnevich J, Wang G and others (2009) Seasonal differences of gene expression profiles in song sparrow (Melospiza melodia) hypothalamus in relation to territorial aggression. PLoS ONE 4(12):e8182

Nagaraju GPC (2011) Reproductive regulators in decapod crustaceans: an overview. J Exp Biol 214:3-16 
Park J, Ohb IS, Kim HC, Yoo S (2010) Variability of SeaWiFs chlorophyll-a in the southwest Atlantic sector of the Southern Ocean: strong topographic effects and weak seasonality. Deep-Sea Res I 57:604-620

Parkinson CL (2002) Trends in the length of the Southern Ocean sea-ice season, 1979-99. Ann Glaciol 34:435-440

> Petalidis L, Bhattacharyya S, Morris GA, Collins VP, Freeman TC, Lyons PA (2003) Global amplification of mRNA by template-switching PCR: linearity and application to microarray analysis. Nucleic Acids Res 31:e142

Pfaffl MW, Horgan GW, Dempfle L (2002) Relative expression software tool (RESTO) for group-wise comparison and statistical analysis of relative expression results in real-time PCR. Nucleic Acids Res 30:e36

Pongsomboon S, Wongpanya R, Tang S, Chalorsrikul A, Tassanakajon A (2008a) Abundantly expressed transcripts in the lymphoid organ of the black tiger shrimp, Penaeus monodon, and their implication in immune function. Fish Shellfish Immunol 25:485-493

Pongsomboon S, Tang S, Boonda S, Aoki T, Hirono I, Yasuike M, Tassanakajon A (2008b) Differentially expressed genes in Penaeus monodon hemocytes following infection with yellow head virus. Biochem Mol Biol Rep 41:670-677

Pura J, Burns G, Thorne MAS, Grubor-Lajsic G, Worland MR, Clark MS (2008) Cold hardening processes in the Antarctic springtail, Cryptopygus antarcticus: clues from a microarray. J Insect Physiol 54:1356-1362

Quetin LB, Ross RM (1991) Behavioural and physiological characteristics of Antarctic krill Euphausia superba Dana. Am Zool 31:49-63

Quetin LB, Ross RM, Clarke A (1994) Krill energetics: seasonal and environmental aspects of the physiology of Euphausia superba. In: El-Sayed SZ (ed) Southern Ocean ecology: the BIOMASS perspective. Cambridge University Press, Cambridge, p 165-184

Quetin LB, Ross RM, Frazer TK, Amsler MO, Wyattevens C, Oakes SA (2003) Growth of larval krill, Euphausia superba, in fall and winter west of the Antarctic Peninsula. Mar Biol 143:833-843

Rakusa-Suszczewski S (1990) Seasonal changes in respiration and biomass of Euphausia superba from Admirality Bay (South Shetland Islands, Antarctica). Pol Arch Hydrobiol 37:305-311

Rozen S, Skaletsky HJ (2000) Primer3 on the WWW for general users and for biologist programmers. In: Krawetz SA, Misener S (eds) Bioinformatics methods and protocols. Methods in molecular biology, Vol. 132. Humana Press, Totowa, NJ, p 365-386

Saborowski R, Buchholz F (1999) A laboratory study on digestive processes in the Antarctic krill, Euphausia superba, with special regard to chitinolytic enzymes. Polar Biol 21:295-304

Samuels RI, Charnley AK, Reynolds SE (1993) A cuticledegrading poteinase from the molting fluid of the tobacco hornworm, Manduca sexta. Insect Biochem Molec 23:607-614

Sanogo YO, Hankison S, Band M, Obregon A, Bell AM (2011) Brain transcriptomic response of threespine sticklebacks to cues of a predator. Brain Behav Evol 77: 270-285

Schmidt K, Atkinson A, Steigenberger S, Fielding S and others (2011) Seabed foraging by Antarctic krill: implications for stock assessment, bentho-pelagic coupling, and the vertical transfer of iron. Limnol Oceanogr 56: 1411-1428

Schmidt K, Atkinson A, Venables H, Pond D (2012) Early spawning of Antarctic krill in the Scotia Sea is fuelled by 'superfluous' feeding on non-ice associated phytoplankton blooms. Deep-Sea Res II 59-60:159-172

> Seear P, Tarling GA, Teschke M, Meyer B and others (2009) Effects of simulated light regimes on gene expression in Antarctic krill (Euphausia superba Dana). J Exp Mar Biol Ecol 381:57-64

Seear PJ, Tarling GA, Burns G, Goodall-Copestake WP, Gaten E, Özkaya Ö, Rosato E (2010) Differential gene expression during the moult cycle of Antarctic krill (Euphausia superba). BMC Genomics 11:582

Smetacek V, Scharek R, Nothig EM (1990) Seasonal and regional variation in the pelagial and its relationship to the life history cycle of krill. In: Kerry KR, Hempel G (eds) Antarctic ecosystems: ecological change and conservation. Springer-Verlag, Berlin, p 103-114

Spicer JI, Strömberg JO (2002) Diel vertical migration and the haemocyanin of krill Meganyctiphanes norvegica. Mar Ecol Prog Ser 238:153-162

Stillman JH, Colbourne JK, Lee CE, Patel NH and others (2008) Recent advances in crustacean genomics. Integr Comp Biol 48:852-868

Storch J, Veerkamp JH, Hsu KT (2002) Similar mechanisms of fatty acid transfer from human and rodent fatty acidbinding proteins to membranes: liver, intestine, heart muscle and adipose tissue FABPs. Mol Cell Biochem 239: 25-33

> Teschke M, Kawaguchi S, Meyer B (2007) Simulated light regimes affect feeding and metabolism of Antarctic krill, Euphausia superba. Limnol Oceanogr 52:1046-1054

Teschke M, Kawaguchi S, Meyer B (2008) Effects of simulated light regimes on maturity and body composition of Antarctic krill, Euphausia superba. Mar Biol 154: 315-324

> Thorpe SE, Murphy EJ, Watkins JL (2007) Circumpolar connections between Antarctic krill (Euphausia superba Dana) populations: investigating the roles of ocean and sea ice transport. Deep-Sea Res I 54:792-810

Tollrian R, Leese F (2010) Ecological genomics: steps towards unraveling the genetic basis of inducible defenses in Daphnia. BMC Biol 8:51

Torres JJ, Donnelly J, Hopkins TL, Lancraft TM, Aarset AV, Ainley DG (1994) Proximate composition and overwintering strategies of Antarctic micronektonic crustacea. Mar Ecol Prog Ser 113:221-232

Towle DW, Smith CM (2006) Gene discovery in Carcinus maenas and Homarus americanus via expressed sequence tags. Integr Comp Biol 46:912-918

Wang B, Li FH, Dong B, Zhang XJ, Zhang CS, Xiang JH (2006) Discovery of the genes in response to white spot syndrome virus (WSSV) infection in Fenneropenaeus chinensis through cDNA microarray. Mar Biotechnol (NY) 8:491-500

- Warner AH, Matheson C (1998) Release of proteases from larvae of the brine shrimp Artemia franciscana and their potential role during the molting process. Comp Biochem Physiol B 119:255-263

> Whitehouse M, Atkinson A, Korb R, Venables H, Pond D, Gordon $M$ (2012) Substantial primary production in the land-remote region of the central and northern Scotia Sea. Deep-Sea Res II 59-60:47-56 